SNEŽANA GOLUBOVIĆ, Institute of Archaeology

Belgrade, Serbia

arheosneska@gmail.com

NEMANJA MRĐIĆ, Institute of Archaeology

Belgrade, Serbia
UDC: 069:904(37)"652";

338.48:902(4-12)"2012”

Original research article

Received: September $13^{\text {th }} 2013$

Accepted: October $15^{\text {th }} 2013$

\title{
T-PAS - PROJECT ON TOURIST PROMOTION OF THE ARCHAEOLOGICAL SITES ALONG THE ROUTE AQUILEIA, EMONA, VIMINACIUM
}

\begin{abstract}
The Project T-PAS, the first project of the European Union in which Viminacium (Archaeological Institute) has participated, started in January 2012. The T-PAS project's main objectives are promoting, both culturally and as a tourist destination, the ancient Roman route connecting Aquileia and Viminacium which passes through Emona (modern Ljubljana). During almost two years of the project several goals are achieved: social-economic study, touristic publication, publication about historical research, three conferences were held from October 2012 till March 2013, touring exhibition was held in every of these three sites, several didactic laboratories, and adaptation of the game for popularization of archaeology among school children.
\end{abstract}

Keywords: T-PAS, Roman routes, Aquileia, Emona, Viminacium.

The Project T-PAS, the first project of the European Union in which Viminacium (Archaeological Institute) has participated, officially started in July 2011, although actually in January 2012. The partners of the T-PAS project met on 12-13th January 2012, in Aquileia, for the kickoff meeting. It was a great occasion to reinforce the cooperation, share the work program for the months to come and to set ambitious objectives to be achieved in areas such as the cultural and tourist valorisation of the old Roman route connecting Aquileia, Iulia Emona and Viminacium (Fig. 1). The T-PAS project's main objectives are promot- ing, both culturally and as a tourist destination, the ancient Roman route connecting Aquileia and Viminacium which passes through Emona (modern Ljubljana).

The project is co-financed by the European Union through the Culture Programme (2007-2013). It is coordinated by the Fondazione Aquileia, which collaborates with two co-beneficiaries, the City Museum of Ljubljana (Emona) and the Serbian Archaeological Institute of Belgrade - Project Viminacium. It was expected to last 24 months, starting on 1st July 2011 and concluding on 30th June 2013. How- 


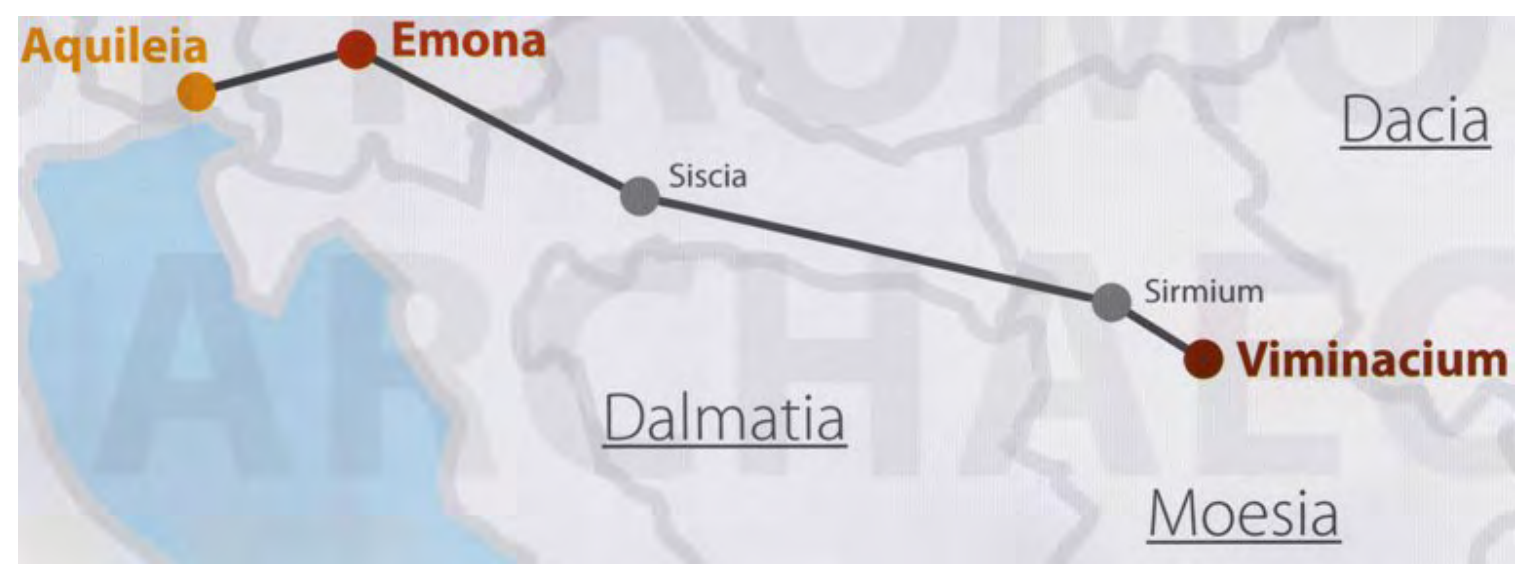

Fig. 1 Map with the Roman road connecting Aquileia, Emona and Viminacium

ever, since it first started in January, the project was prolonged until 30th September 2013. Three ancient cities included in the project, Aquileia, Emona and Viminacium, developed and flourished in the period from the 1st to the 4th century $\mathrm{AD}$, thanks to, among other things, the good road network. The most important road was the one connecting these three cities. The importance of these cities in the period of antiquity was enormous.

AQUILEIA - Representative: Fondazione Aquileia (Fig. 2)

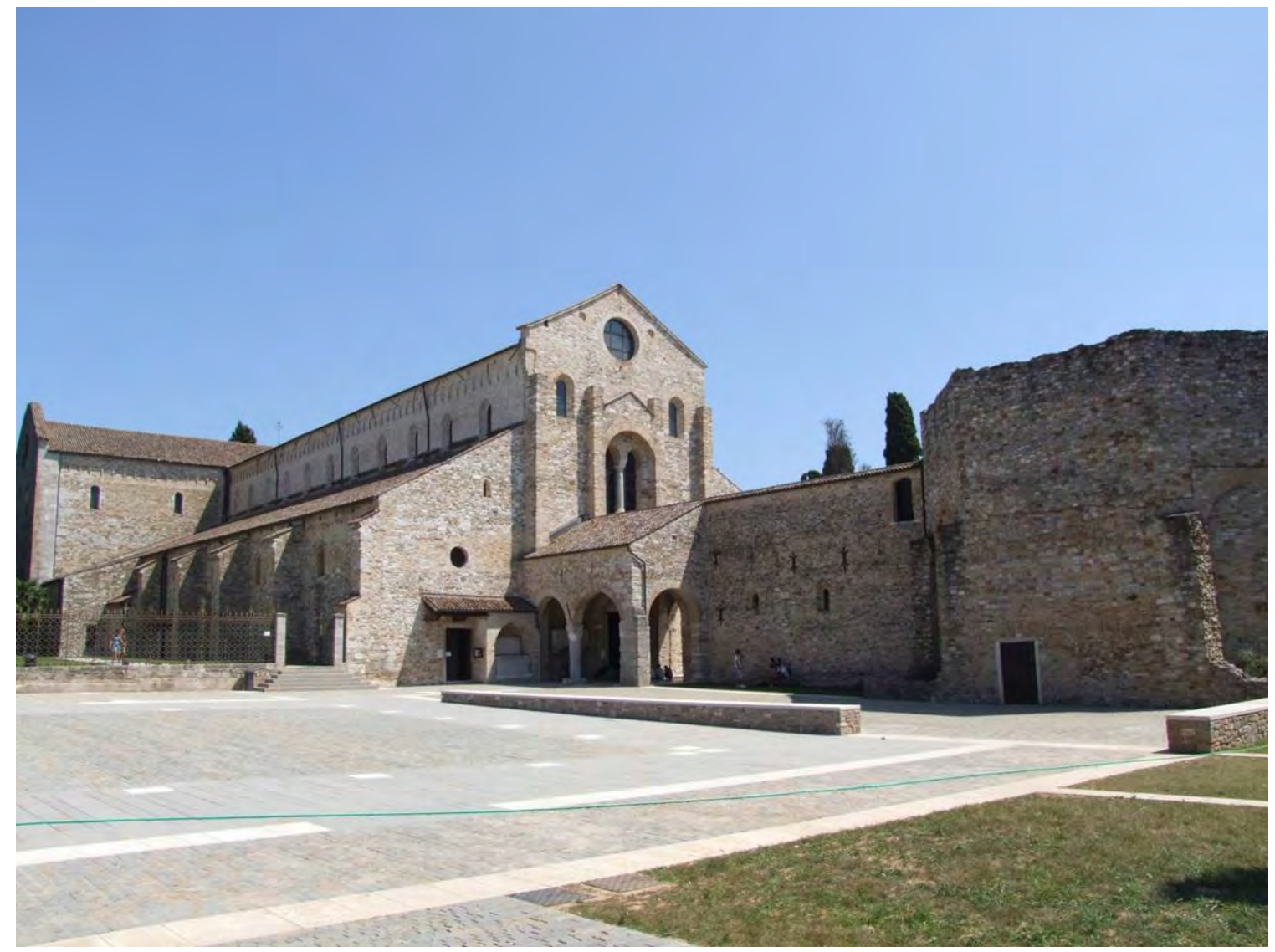

Fig. 2 The Basilica of Aquileia 
The colony of Aquileia was founded in 181 $\mathrm{BC}$, on the banks of the River Natiso, serving as a frontier garrison for the Roman conquest of North-Eastern Italy.
Built on a polygonal perimeter, the city grew fast through the fruits of its farming and animal husbandry and the development of largescale trade, enabled by its river port. Aquileia

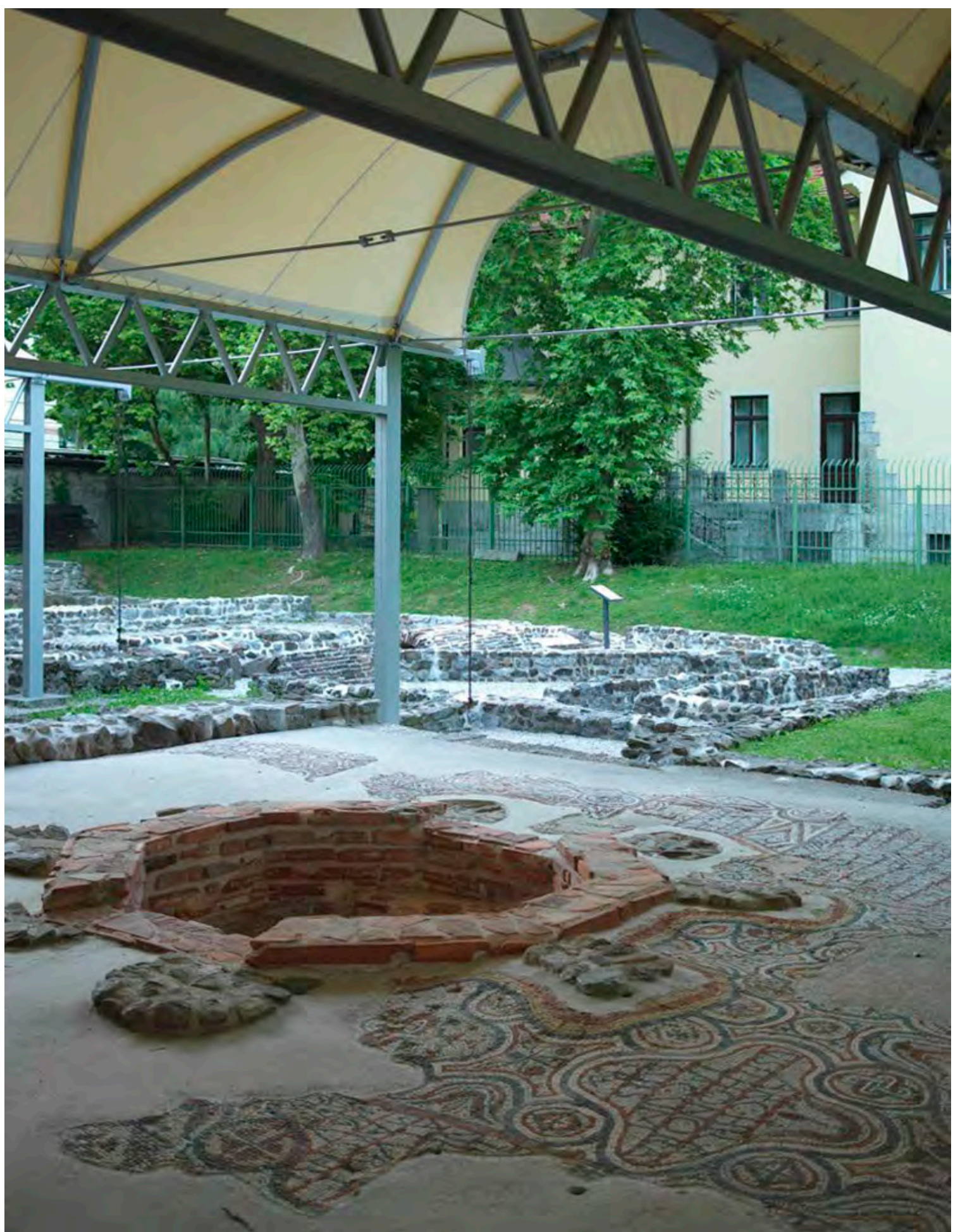

Fig. 3 Emona - Early Christian baptisterium 
became one of the most important cities in Italy. Over time, a complex road network linked it to the rest of the peninsula and, during the 1st century $\mathrm{BC}$, also to the Illirian, Istrian and Danube areas. During the 4th century, imperial residences were built in Aquileia and it was the seat of the Imperial Mint between 284 and 425 AD. Of particular importance was the construction, in the second decade of the 4th century, of a basilica.The patriarchal basilica, an outstanding building with an exceptional mosaic pavement, played a key role in the evangelisation of a large region of central Europe.This dominant feature of Aquileia was constructed as a horseshoe-shaped complex of three main halls.However, this proved to be inadequate to house the worshippers and pilgrims so, in $345 \mathrm{AD}$, a vast structure replaced the northern arm. It later had to undergo a series of renovations and modifications that were to last until modern times. In $452 \mathrm{AD}$, the city was conquered by Attila and the Huns and suffered serious damage.This led to the northern part of the city being progressively abandoned (Aquileia 2012).

EMONA - Representative: The City Museum of Ljubljana (Fig. 3)

In the first decade of the 1st century, in an area of what is now Ljubljana, along the left bank of the Ljubljanica River, the Romans established their colony Colonia Iulia Emona. The city was settled by colonists from northern Italy. Emona flourished from the 1st to the 5th century. It was laid out in a rectangle with a central square or forum and a system of rectangular intersecting streets, between which were sites for buildings.The Roman Emona sites in Ljubljana can be seen in several parts to the west of the old town centre, for example the house with the beautifully reconstructed floor mosaics.

From the late 4th to the late 6th century, Emona was the seat of a bishopric. The intensive contacts pursued by the early Christian community of Emona with the ecclesiastical circle of Milan are reflected in the architecture of the early Christian complex. The remains of a baptistery with a pool, mosaics, and part of a portico can also be seen in the centre of the modern town (Županek 2010: 9-16).
VIMINACIUM - Representative: The Archaeological Institute of Belgrade (Fig. 4)

Viminacium, a Roman town and important military centre of the Upper Moesia, was established at the confluence of The Mlava with The Danube (Mirković 1968: 56; Mirković 1986). It was located on the important military route leading from Singidunum to the south, towards Naissus. Three roads crosscut this area, connecting the town with the eastern, western and southern regions of the Roman Empire. At the same time, Viminacium was an important military and civil Danubian port (Popović 1968: 24-49).

Viminacium was the fort of the Legio VII Claudia erected on the right bank of The Mlava, and settled almost continuously from the 2nd to 4th century. A civil settlement was established beside the military one, and was noted in epigraphic sources. Its traces have been confirmed archaeologically to the west of the fort. The settlement received municipal status under Hadrian in 117 . The status of colony was obtained at the end of 239, under Gordian III. Permission to mint coins was also granted at this time. In the 4th century, it became an Episcopal centre. Two bishops are confirmed: Amantinus and Cyriacus. Its economic downfall started in the mid-3rd century and accelerated in the late 3rd and 4th century. In 441, during the Hunic invasion, Viminacium was destroyed, but was rebuilt under Justinian, 80 years after the Huns' withdrawal (Mirković 1968: 58-73).

Over the course of 400 years, cemeteries were established beside the fort, city and canabae legionis (Pećine, Više Grobalja, Na rupi, Kod bresta), encompassing a chronological span between the 1 st and the 4th centuries (Jovanović 1984; Zotović, Jordović 199; Korać, Golubović 2009). Since the 1970s, due to the construction of a thermo electric power plant, more than 13,000 graves with 30,000 pieces of inventory have been excavated.

Owing to the general importance of the road in Roman times, the T-PAS project is based on a complex work plan focused on increasing scientific knowledge based on archaeological excavations and also on tourist interest in the ancient Roman route connecting these three important sites. Naturally, along the road there are 


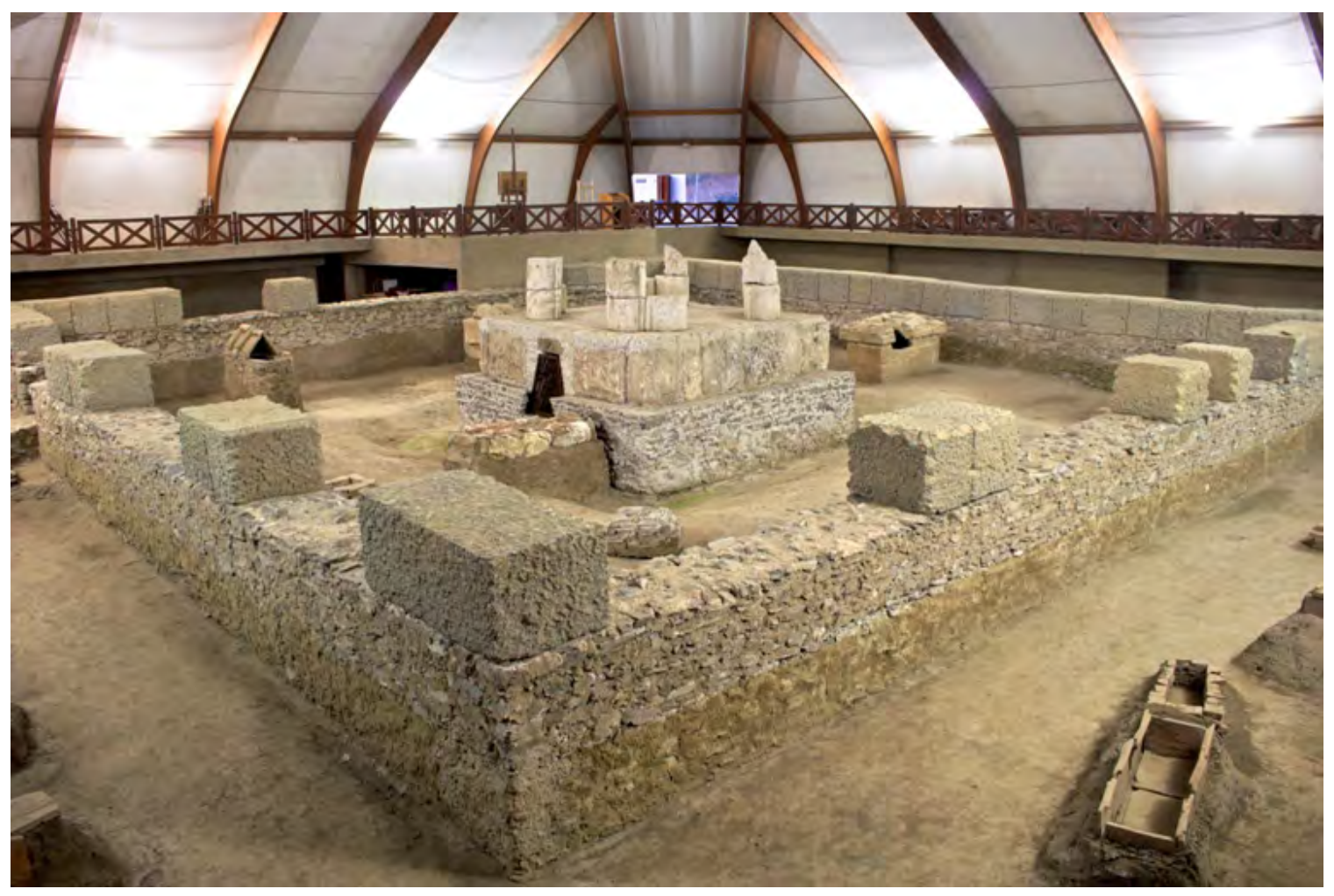

Fig. 4 Viminacium mausoleum

also some very important Roman sites and other Roman cities which could have been included in the project such as, for example, Siscia. At the very beginning, during the kick-off meeting in Aquileia, when the duties of each partner were being discussed, it was agreed that the Archaeological Institute of Belgrade would have the obligation to print leaflets and other promotional material such as notebooks, pencils and USB sticks. The City Museum of Ljubljana would create a web-site, while the Foundation Aquileia would be in charge of publications.

The main activities which were foreseen included many joint activities for the international partnership. First was the preparation of a mutual report on the state the 3 archaeological sites. On 21st June 2012, at the Final Forum for the presentation of the results of the research on Agenda 21 for culture, in Aquileia, Fondazione Aquileia presented the results of the participatory actions carried out in Aquileia with the support of Focus lab s.r.l. to the public. This was aimed at sharing best practices on the implementation of the Agenda 21 for culture and identifying cultural and economic development opportunities for the city. An open Forum de- signed to present the objectives of foreseen activities at the beginning of the works, followed by the organisation of various focus groups, were conceived to perform in-depth analysisof particular issues of interest with participatory methodologies.

The Viminacium team started early in the spring of 2012 with the preparation and design of materials that would be used as promotional material for the project T-PAS. The panels, which were not planned in the beginning, turned out to be very useful during all the activities related to the project dedicated to "IUVENES ROMANI" or "young Romans" with the intention of bringing Roman culture closer to school children. Their first use was on 20th June 2012, when the celebration of "100 years of Požarevac Gymnasium" was organised in Domus. During that celebration, a competition of Latin language skills took place (Fig. 5). In addition, they were used at the "Manifestation of Roman everyday life" which took place at Viminacium on every Friday in June under the name of IUVENES ROMANI ("Young Romans" or "Children in the Roman period"). These events were designed for slightly younger school children (Fig. 6). 


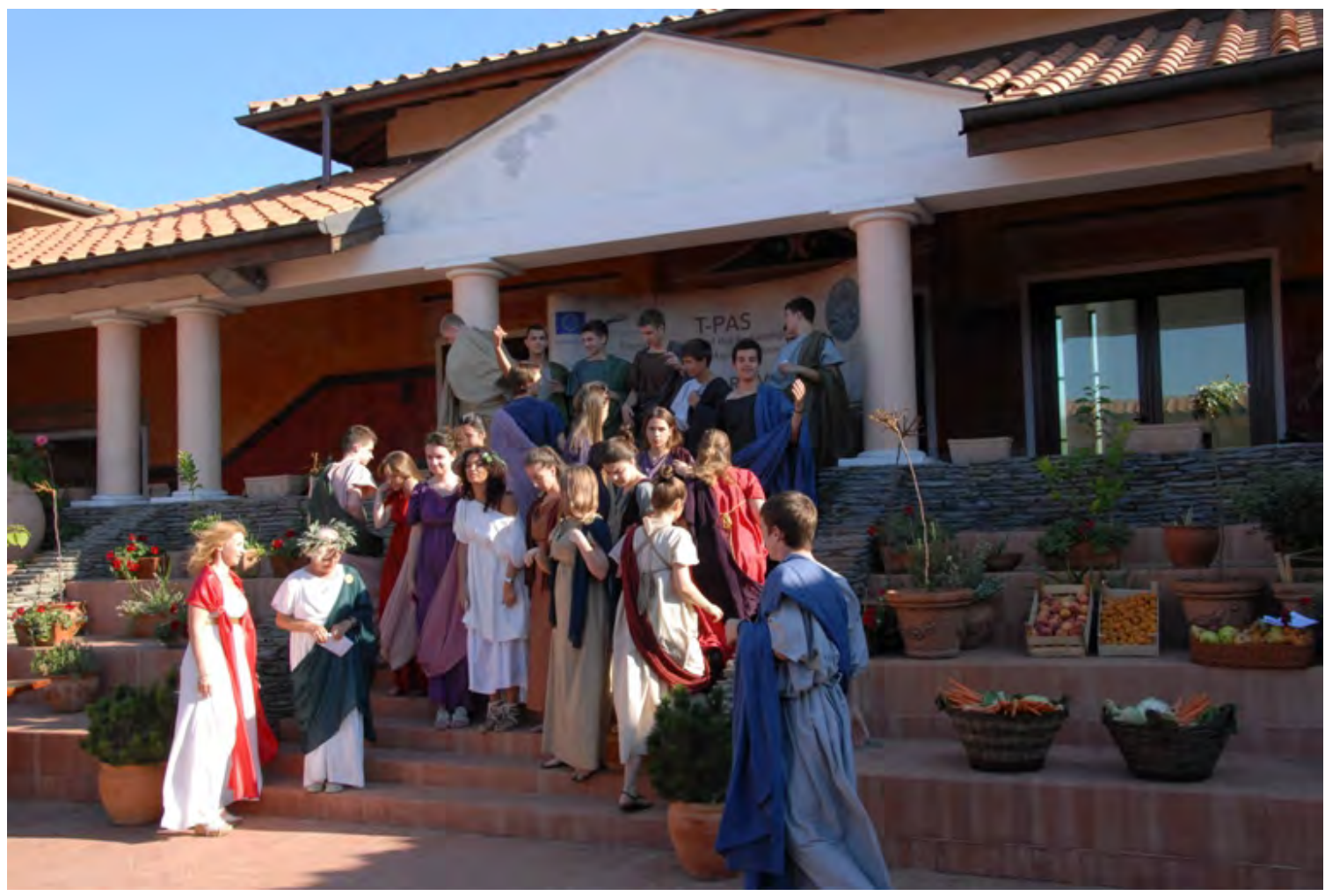

Fig. 5 Celebration of Požarevac Gymnasium

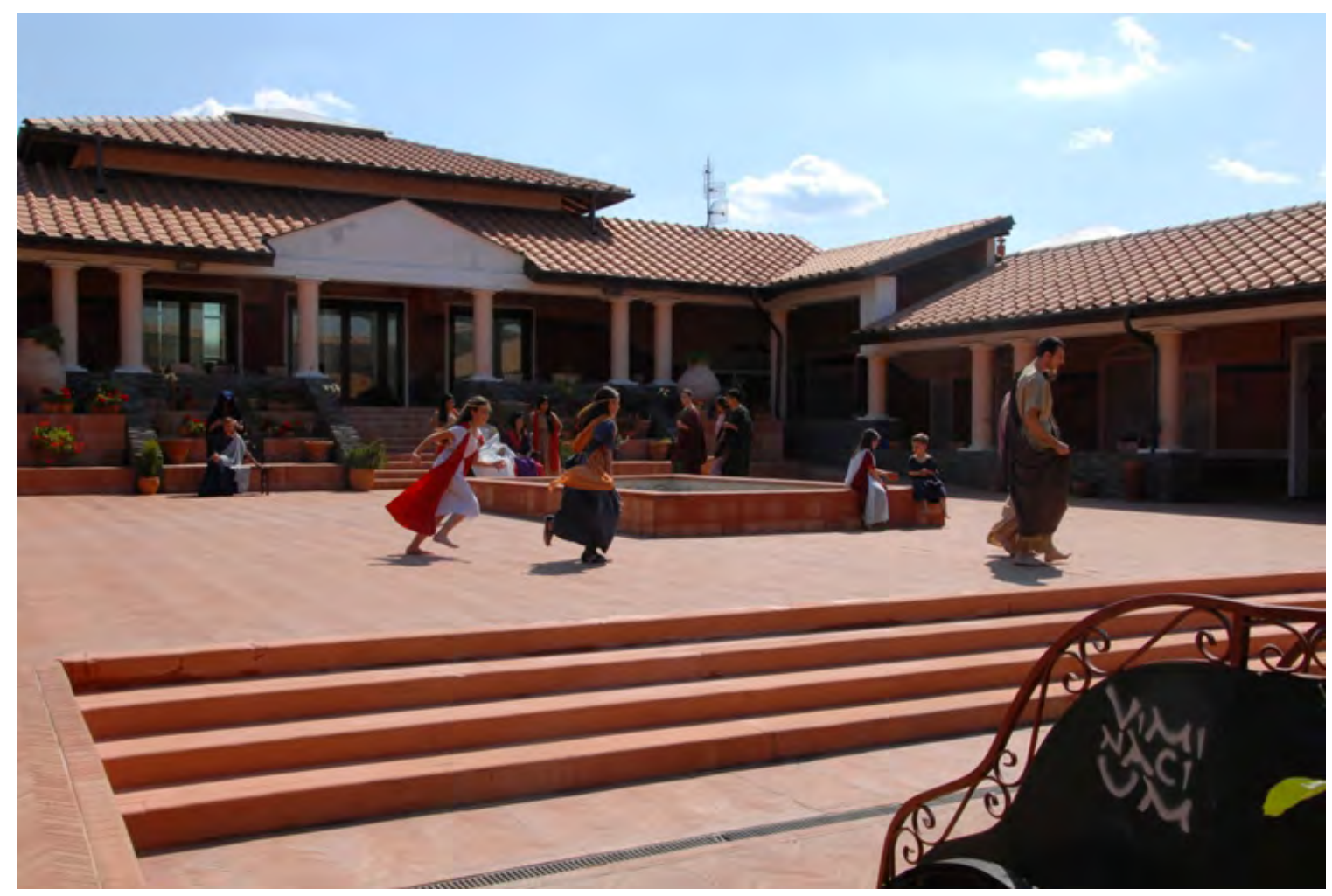

Fig. 6 Manifestation of Roman everyday life IUVENES ROMANI 
The next activities included promotions at national fairs. For that purpose each partner had the leaflet in English and its own language which were intended to be distributed at national fairs. Fondazione Aquileia first distributed them at the national fair in Assisi in September 2012. From 12th to 15th November 2012, Fondazione also participated in the Borsa Mediterranea del Turismo Archeologico, held in Paestum. The Archaeological Institute of Belgrade participated with a stand at the International Fair of Tourism (ITTFA), held in Belgrade from 21st to 24th February 2013. It was a great opportunity to promote the T-PAS project's objectives and results by distributing flyers, posters and merchandising material and informing visitors of the financed action's progress (Fig. 7). In the months before the national fairs, activities were intensified around socio-economic analysis.This started with the compilingof the questionnaires unique for each partner and was followed by analysis and a comprehensive study. This required a huge effort on the part of colleagues dealing with tourism and management and also included experts in this sector. The studies were completed on time and will provide guidelines for future joint actions. By the middle of 2012, the Archaeological Institute finished the socio-economic analyses with concrete development proposals, the preparation for research and the organisation of participatory actions connected to Agenda 21 for Culture.

In conclusion what is Viminacium's contribution? Aquileia is a well-known and frequently visited Roman city (1, 300, 000 visitors per year) and Emona is situated in the modern town of Ljubljana and easily approachable butViminacium is in a plain field far from the urban zone. Nevertheless, its example shows how to achieve the successful touristic development of a cultural and historical place, on both the national and international level. It offers great support to the local socio-economic development, even though its considerationof the importance of culture and heritage is undeveloped. It lacks the financial support of the state and is always having to make compromises with, it seems, conflicting sides of the industry.This is all achieved with the great efforts of its developers, scientists and exceptional local enthusiasts. This is the recipe of suc- cess of Viminacium, from which we are trying to extract the formula for the future development of archaeological sites globally.

In June 2012, the partners started preparing for the touring exhibitions. It is important to point out that all exchanges of photos, drawings and texts in integral versions or translations would not have been possible without a stable internet connection. In the case of Aquileia and Emona, considering their urban nature,this stability was to be expected. However, in the case of Viminacium, in the middle ofa field with Wi-Fi, it provided perfect proof of the function of an on- site,scientific-research centre in a rural setting. After a number of months, the partners completed the work on the panels with photos and text. The panels tell the story of the ancient road and explain its commercial and military role, providing a particular focus on daily life during the Roman age. The touring exhibition was first opened during the conference of archaeological parks in the framework of the T-PAS project, held in Ljubljana on 23rd October 2012. In January 2013, Fondazione Aquileia hosted the exhibition in "Süd Halle" in Aquileia. The exhibition was open to visitors until 20th February 2013. Due to difficulties with customs and shipments from the EU to Serbia, the touring exhibition only arrived at Viminacium at the beginning of July and was open to visitors until the end of September (Fig. 8).

Three Conferences were held from October 2012 to March 2013. The first was on 23rd October in Ljubljana under the title of "Archaeological parks - Conservation, presentation, promotion", followed on 19th of January, in Aquileia by "Archaeology and archaeological parks. Comparison of experiences", then, finally, on 20th of March at Viminacium "Archaeological parks - Formula for development - Preservation of the cultural, historical and natural heritage with promotion of tourism" (Fig. 9). These events had great scientific value, bringing together international experts on archaeology and archaeological parks, whilst also giving cultural operators the possibility to learn from examples of best practices for the management of archaeological parks and activities of cultural and tourist valorisation of archaeological sites. The three partners had a mid-term meeting at Viminacium on 6th to7th of November 2012 which was also considered as a study visit for Fondazi- 


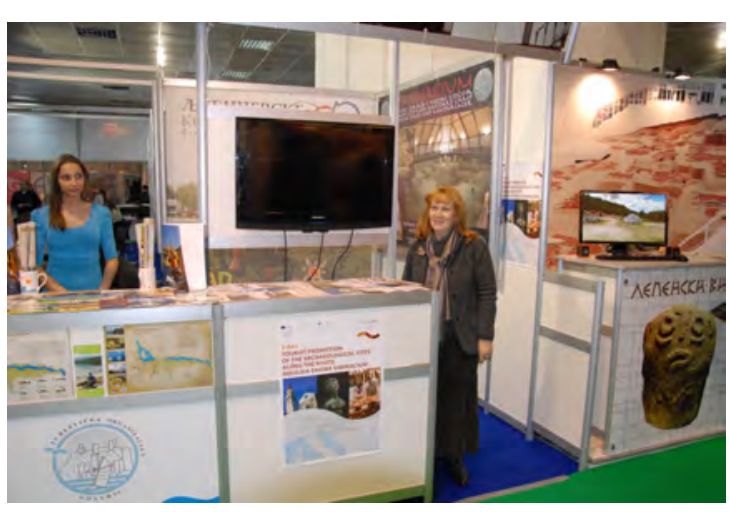

Fig. 7 Promoting T-PAS project at Belgrade Fair

one Aquileia and the City Museum of Ljubljana. The partners had the opportunity to share achieved results, plan future activities and discuss critical issues. On the occasion of the meeting, the partnership also took part in, along with some invited external experts, a study visit to the archaeological site of Viminacium, learning in depth its invaluable heritage and benefiting from a very positive exchange of know-how and best practices on didactic, cultural and tourist promotion and scientific activities. During the meeting an idea from the Viminacium team to create a new didactic game gained the support of all the included members. The following months were especially testing, but an exciting was timespent composing thespecial design and suitable content for the game. Naturally it resulted in an interesting, useful and visually engaging game which was of great benefit to the workshops for children.

The first didactic laboratories were organised in May, in Viminacium. Specifically, the Archaeological Institute realised, with the support of The Centre for New Technology and local schools, a set of didactic laboratories focused on archaeology and, in particular, on the Roman route from Aquileia to Viminacium, via Emona. A particularly special occasion was the presentation of the game produced specifically for the project T-PAS, which proved to be a great success. After the presentation, a photo contest was also organised, stimulating pupils to take pictures of particular details of the archaeological site. At Viminacium, on 18th May, an exhibition dedicated to 17 centuries of The Milan Edict, in cooperation with The National Museum in Belgrade, was opened. This lasted until 18th June. This was the perfect occasion for the photo contest,

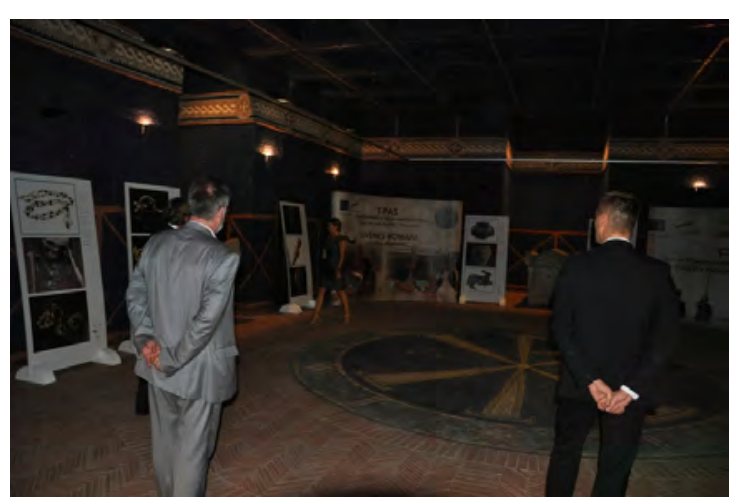

Fig. 8 Opening of Touring Exhibition in Domus Scientiarum at Viminacium

because pupils were able to take photos of the most valuable objects from the late antique period and demonstrate their artistic talents (Fig. 10). In July and August 2013, at the Viminacium site, with the support of The Centre for the Popularisation of Science, the Archaeological Institute realised, with schools from Belgrade, a set of didactic laboratories in the framework of a summer school of science (from Thursday until Saturday). On the Friday, the focus was on archaeology and, in particular, on the Roman Aquileia-Emona-Viminaciumroute. Children were involved in lessons on Roman history and archaeology, in practical workshops for the production of Roman pottery, as well as with practical participation in field work, such as excavations at the archaeological site of Viminacium (Fig. 11).

The didactic laboratories on archaeology were organised in Aquileia in June. Fondazione Aquileia, with the support of Julia Global Service, realised a set of didactic laboratories with local schools. Besides lessons on Roman history and archaeology, children were involved in practical workshops for the production of Roman lamps and Roman games and in outdoor visits of the main elements of the heritage of the city of Aquileia, including Museo Archeologico Nazionale. A photo contest was also organised, "Lo scatto antico", stimulating pupils to take pictures of particular details of the archaeological site. The partners of the T-PAS project met in Ljubljana on 10th to 11th July 2013 for a final meeting (Fig. 12), which gave them the opportunity to share achieved results, plan the project closure and to discuss its impacts and results. Immediately after, on 12th July 2013, Fondazione Aquileia and the Archaeological Institute of Belgrade were 


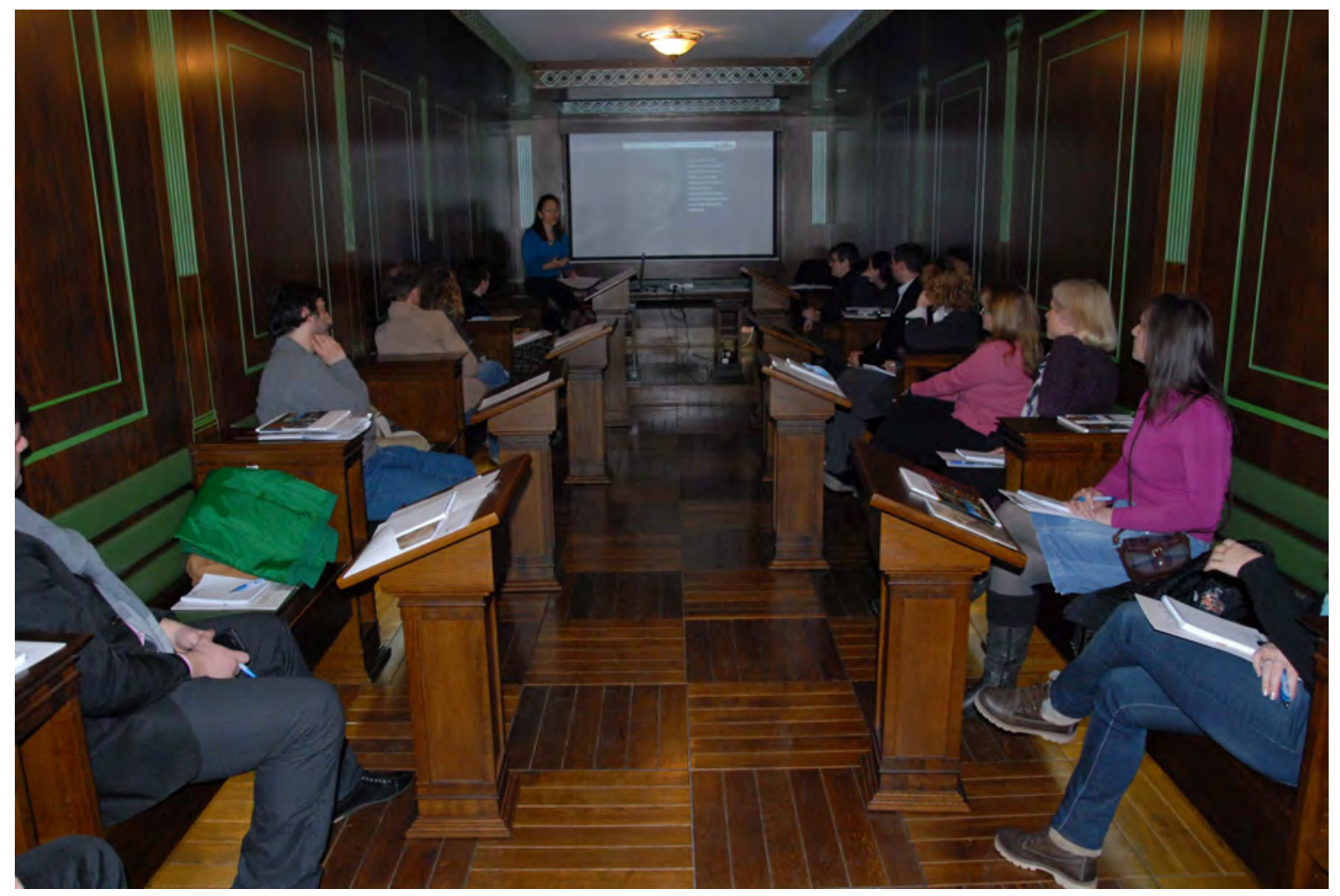

Fig. 9 Conference about archaeological parks in Domus Scientiarum at Viminacium

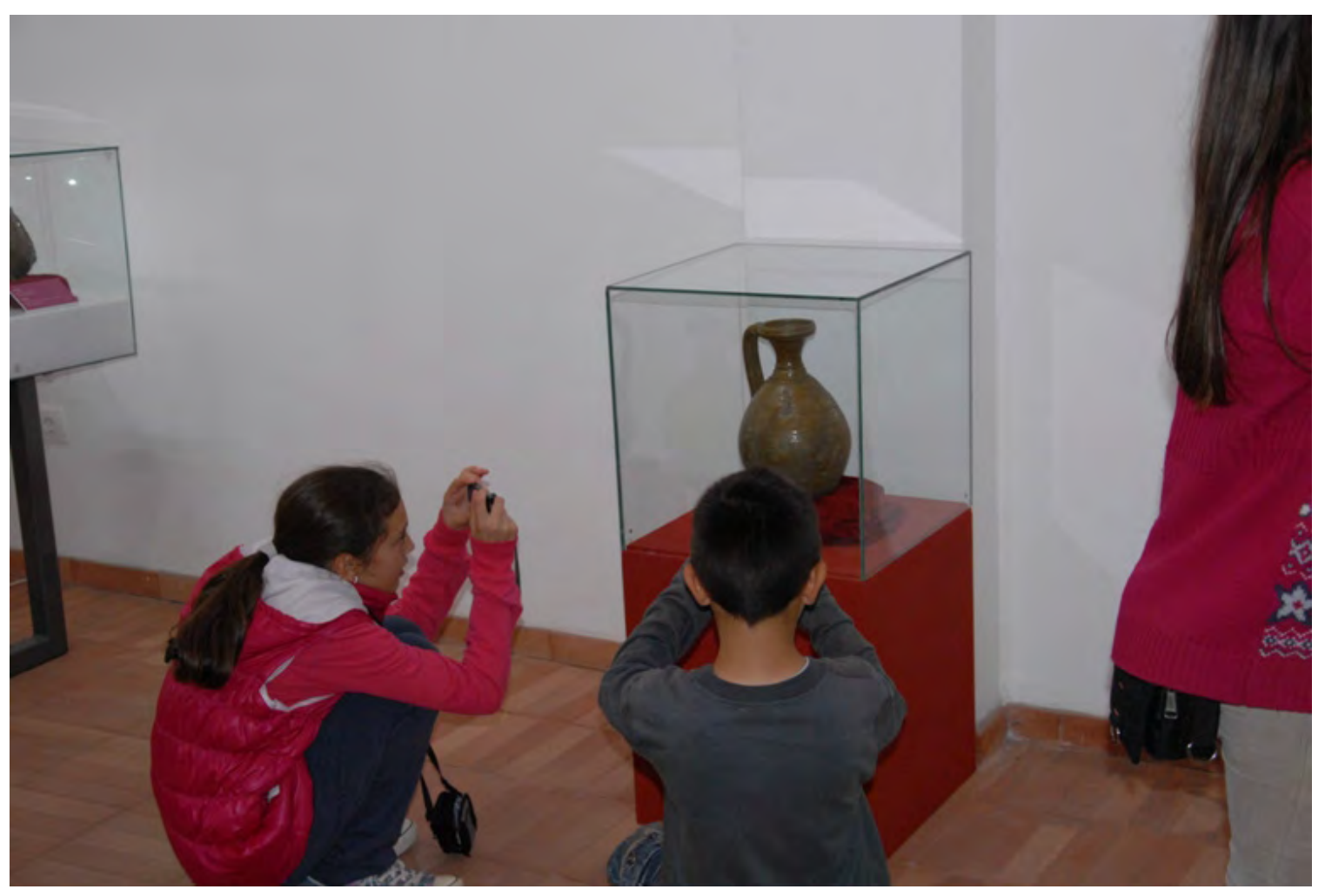

Fig. 10 Photo-contest for school children 


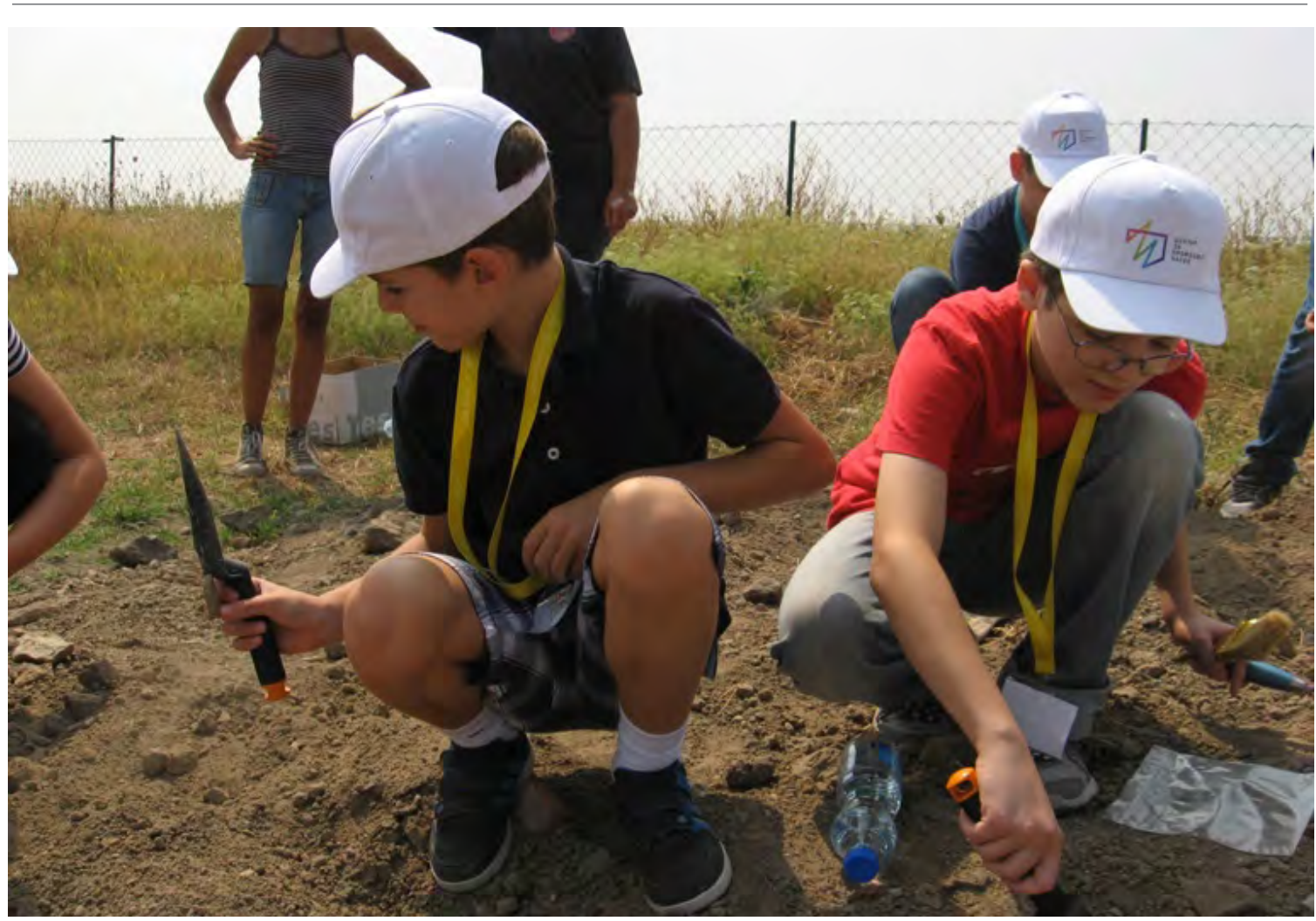

Fig. 11 Summer school of science - field work

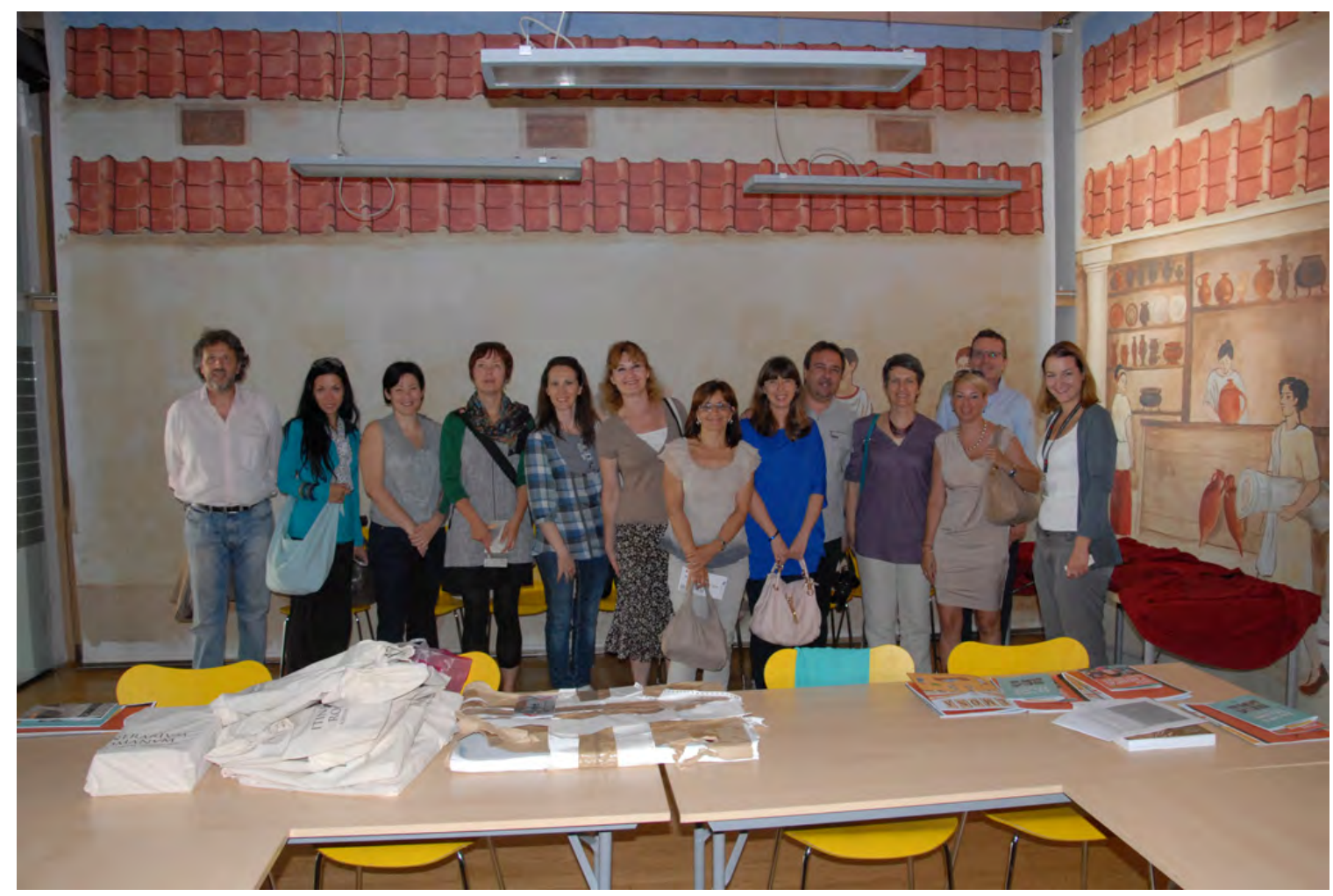

Fig. 12 Final meeting at Ljubljana 
involved, together with several invited external experts, in a study visit to the archaeological site of Emona. This was organised by the City Museum of Ljubljana. It was a great opportunity to get to know the invaluable heritage of the Roman city and to share and transfer best practices related to scientific, didactic and cultural and tourist promotion activities among cultural operators. The Archaeological Institute of Belgrade completed a study visit to the archaeological site of Aquileia on 13th July 2013. Fondazione Aquileia hosted a study visit to the Roman city for staff and the Archaeological Institute of Belgrade's external invited experts. On that occasion they had the opportunity to learn about the invaluable heritage of Aquileia and to visit the exhibition "Costantino e Teodoro. Aquileia nel IV secolo”.

After considering creating a tourist opportunity for schools that would include all three sites, it was concluded that it would be easier for the partners from Aquileia and Emona. This is because for schools from Serbia it is much more complicated to organise an excursion that involves three different countries, especially for those children under 11 . This activity could not, therefore, be fulfilled equally by all partners.

Nevertheless, at the same time, the members of all three teams worked on a tourist publication, as well as a historical-archaeological analysis of the Roman road that connected the three sites.

In conclusion, the aim of the whole project is not only to share the experiences of the partners in the field of the popularisation of science, but also to spread knowledge among school children about the three sites including the roman roads and, inevitably, the development of Roman Empire as a whole. Only in this way will it become familiar to future generations. Therefore, the goal of the project is to promote the protection and preservation of our archaeological heritage, but also the promotion of archaeology and other sciences. It helps by improving the educational programs in schools in Italy, Slovenia and Serbia. In other words, it expands the knowledge of the younger generation about our own, European and world cultural-historical heritage. As a part of the route "Roads of Roman Emperors", it will become a part of a global scientific and cultural network. Cultural tourism is a specific aspect of tourism which, among others, connects cultural-histori- cal places and allows tourists to learn something about one (in our case more than one) nation's history and folklore. The popularisation of science is necessary in order to develop this kind of tourism, but it cannot occur without the basic science, archaeology, which provides the conditions necessary for economic development.

\section{BIBLIOGRAPHY}

\section{Aquileia 2012}

Aquileia: Crossroad of the Roman Empire: economy, society, art - Documentary exposition on the history of Aquileia.

Županek, B. 2010

Emona: rimsko mesto in njegova dediščina, in Emona: myth and reality; ed. B. Županek, Ljubljana, 9-26.

\section{Mirković, M. 1968}

Rimski gradovi na Dunavu u Gornjoj Meziji, Beograd.

\section{Mirković, M. 1986}

Inscriptions de la Mésie Supérieure, Vol. II, Beograd.

\section{Popović, V. 1968}

Uvod u topografiju Viminacijuma, Starinar XVIII, 24-49.

\section{Jovanović, B. 1984}

Les sepultures de la necropole celtique de Pećine pres de Kostolac (Serbie du nord), Etudes Celtiques XXI, Paris, 63-93.

\section{Zotović, Lj., Jordović Č. 1990}

Viminacium 1 - nekropola Više grobalja, Beograd.

Korać, M., Golubović, S. 2009

Viminacium - Više Grobalja 281-530 (kremacija)

268-560 (inhumacija), Tom II, Beograd. 


\section{REZIME}

\section{T-PAS - PROJEKAT TURISTIČ- KE PROMOCIJE ARHEOLOŠKIH LOKALITETA DUŽ RIMSKOG PUTA KOJI SPAJA AKVILEJU, EMONU I VIMINACIJUM}

Ključne reči: T-PAS, rimski putevi, Akvileja, Emona, Viminacijum.

Projekat T-PAS, prvi projekat Evropske unije u kome je učestvovao Viminacijum (Arheološki institut), počeo je u januaru 2012 godine. To je bila odlična prilika da se uspostavi saradnja, napravi zajednički program rada, postave ambiciozni ciljevi koje su zatim i ostvareni u oblastima kao što su kulturne i turističke valorizacije starog rimskog puta koji povezuje Akvileju, Emonu i Viminacijum. Projekat je sufinansiran od strane Evropske unije preko Programa Kultura 2007-2013. i njime je koordinirala Fondacija Akvileje (Akvileja) sa dva partnera: Muzejom grada Ljubljane (Emona) i Arheološkim institutom (Beograd), odnosno projektom Viminacijum. Na samom početku dogovoreno je da će Arheološki institut imati obavezu da štampa letke, postere i drugi promotivni materijal, Muzej grada Ljubljane će kreirati sajt, a Fondacija Akvileja će biti zadužena za publikacije. Usledile su aktivnosti poput promocija na nacionalnim sajmovima, organizovanje tri konferencije u periodu od oktobra 2012. do marta 2013. godine o arheološkim parkovima, konzervaciji i izaštiti kulturnog nasleđa. Tokom gotovo dve godine projekta postignuto je nekoliko ciljeva: završena je socijalno-ekonomska studija, odštampana je turistička publikacija, elektronska publikacija, publikacija o naučno-istorijskim istraživanjima, realizovane su putujuće izložbe fotografija na svakom od ova tri lokaliteta koje su bile veoma posećene, održano je više didaktičkih laboratorija u kojima je učestvovalo nekoliko stotina dece i, kao potpuno novi proizvod izvan prvobitnih planova, adaptirana je igra dizajnirana za popularizaciju rimskih puteva za decu školskog uzrasta. 